\title{
GREEN SYNTHESIS OF ISOPULEGOL FROM CITRONELLAL CATALYSED BY ZEOLITE BASED SOLID ACID CATALYSTS
}

\author{
Indri Badria Adilina and Egi Agustian \\ Research Centre for Chemistry, Indonesian Institute of Sciences \\ Kawasan Puspiptek Serpong, Tangerang 15314 \\ Alamat korespondensi: indr002@lipi.co.id
}

\begin{abstract}
Abstrak: Zeolit alam (NZ) telah dimodifikasi dengan penambahan asam (H-NZ) dan diaplikasikan sebagai katalis asam padat untuk green sintesis isopulegol dari minyak sereh wangi. Sintesis ini melibatkan reaksi siklisasi sitronelal menjadi isopulegol pada suhu 50 sampai $120^{\circ} \mathrm{C}$. Aktifitas katalis $\mathrm{H}-\mathrm{NZ}$ terbukti lebih tinggi dari katalis H-ZSM5 yang tersedia di pasar dan lebih unggul dari katalis asam padat berbasis bentonit. Perolehan terbaik sebesar $87 \%$ isopulegol diperoleh menggunakan katalis $\mathrm{H}-\mathrm{NZ}$ pada $100^{\circ} \mathrm{C}$ selama 3 jam tanpa penggunaan pelarut reaksi.
\end{abstract}

\section{Kata kunci: Isopulegol, Sitronelal, Minyak Atsiri, Zeolit, Katalis Asam Padat}

Abstract: Natural zeolite (NZ) was modified by acid treatment (H-NZ) and applied as a solid acid catalyst in the green synthesis of isopulegol from the essential oil of citronella. The synthesis involved a cyclisation reaction of citronellal to isopulegol at a temperature range of 50 to $120^{\circ} \mathrm{C}$. The catalytic activity of $\mathrm{H}-\mathrm{NZ}$ was higher than that of the commercially available H-ZSM5 and much superior to bentonite based solid acid catalyst. The best yield of $87 \%$ isopulegol was obtained using the $H-N Z$ catalyst at $100^{\circ} \mathrm{C}$ for 3 hour without the use of any solvent.

Keywords: Isopulegol, Citronellal, Essential Oil, Zeolite, Solid Acid Catalyst

\section{INTRODUCTION}

Isopulegol is a fine chemical with characteristic peppermint odor widely used in the manufacture of fragrances having blossom compositions (Newman, 1998). Currently, isopulegol is formed as an intermediate in the production of menthol from myrcene. The process involves a three steps sequence using a homogeneous chiral $\mathrm{Rh}(\mathrm{I})$-BINAP catalyst as the key step (Jacob et al., 2003).

Considerable effort has been devoted to the production of isopulegol from other readily renewable raw materials which may simplify and create a greener synthetic process, such through the cyclisation reaction of citronellal, a biomass-derived compound of the essential oil of citronella.

Homogeneous catalyst have been reported active for the cyclisation of citronellal, however, synthesis over a solid acid catalyst is more favorable since the selected heterogeneous catalyst was proven to give an environmentally-friendly process that eliminates harmful procedures of product separation.

Examples of solid acid catalyst in the cyclisation of citronellal include a hydrous zirconia catalyst which gave $60 \%$ yield of isopulegol, some other available solid acid catalyst such as Amberlyst and Nafion show high activity for the cyclisation, but the selectivity toward isopulegol was poor (Chuah et al., 2001). They catalysed side reactions such as hydration, cracking, and etherification of isopulegol.

Zeolites are aluminosilicate minerals known to have Lewis acidity by which when modified with acid treatment may generate numbers of Bronsted acid sites (Centi and Peranthoner, 2008). It was found that the presence of both Lewis and Bronsted acidity is essential to increase the selectivity of isopulegol. In this research, we have focused on developing a green synthesis of isopulegol from citronellal using a modified natural zeolite as the selected solid acid catalyst.

\section{MATERIAL AND METHOD Material}

Natural zeolite was obtained from PT. Lingga Madu Perkasa and H-ZSM5 was purchased from Zeolyst International. Citronellal (85\%) was isolated from the essential oil of citronella by a fractional distillation method.

\section{Preparation of zeolite based solid acid catalyst}

NZ (5g) was modified by acid treatment using $30 \mathrm{~mL} 6 \mathrm{M}$ sulfuric acid for $3 \mathrm{~h}$. The resulting H-NZ was then washed with adequate amount of water, filtrated, and dried at $100^{\circ} \mathrm{C}$ for $2 \mathrm{~h}$

\section{Cyclisation of citronellal to isopulegol}

The cyclisation of citronellal was conducted in a round-bottomed flask equiped with a magnetic stirrer and a reflux condensor. Citronellal $(25 \mathrm{~mL})$ was placed following the addition of zeolite based solid acid catalyst $(0.8 \mathrm{~g})$. The cyclisation reaction was carried out at temperatures of 50 to $150^{\circ} \mathrm{C}$ for $3 \mathrm{~h}$. Products were analyzed using a Shimadzu 14A Gas Chromatograph with a HP-Innowax capillay column. 


\section{RESULTS AND DISCUSSION}

Cyclisation of citronellal using zeolite based solid acid catalyst

\section{Effect of temperature}

The effect of temperature was investigated using $\mathrm{H}-\mathrm{NZ}$ catalyst at a temperature range of 50 to $120^{\circ} \mathrm{C}$ as shown in Table 1.

Table 1. Cyclisation of citronellal to isopulegol using various zeolit based solid acid catalysts

\begin{tabular}{|c|c|c|c|}
\hline Entry & Catalyst & $\begin{array}{c}\text { Temperature } \\
\left({ }^{\circ} \mathrm{C}\right)\end{array}$ & $\begin{array}{l}\text { Selectivity } \\
(\%)^{\mathrm{a}}\end{array}$ \\
\hline 1 & H-NZ & 50 & 19 \\
\hline 2 & H-NZ & 100 & 86 \\
\hline 3 & $\mathrm{H}-\mathrm{NZ}$ & 120 & 61 \\
\hline 5 & NZ & 100 & 46 \\
\hline
\end{tabular}

At a lower temperature of $50^{\circ} \mathrm{C}$, only $19 \%$ selectivity toward isopulegol was observed (Entry 1). This low selectivity was possibly due to lack of energy needed for the reaction to take place. It is known that heating increases the frequency of collision of molecules which then an effect the amount of isopulegol formed. At an elevated temperature of $100^{\circ} \mathrm{C}$ on the other hand, an increase in isopulegol selectivity up to $86 \%$ was achieved (Entry 2). Meanwhile at a higher temperature of $120^{\circ} \mathrm{C}$, the conversion showed a decrease trend of $61 \%$ (Entry 3). Citronellal can undergo other side reactions besides the desired cyclisation reaction, such as dehydration, cracking, or etherification. The amount of by-products formed is affected by the acid strength of the catalyst and the reaction temperature. Cyclisation using catalyst precursors such as the parent NZ also showed some activity, however, the untreated NZ only gave $46 \%$ selectivity toward isopulegol (Entry 4).

\section{Effect of catalyst amount}

The effect of catalyst amount was examined for the cyclisation reaction using $\mathrm{H}-\mathrm{NZ}$ and commercially available $\mathrm{H}-\mathrm{ZSM} 5$ catalyst. The reaction temperature was kept constant at $100^{\circ} \mathrm{C}$ and the amount of catalyst was varied in a range of 2.5 to $7.5 \mathrm{wt} \%$ as summarized in Table 2.

In the case of $\mathrm{H}-\mathrm{NZ}$ catalyst, a higher isopulegol selectivity of $88 \%$ was observed when $2.5 \mathrm{wt} \%$ amount of catalyst was used (Entry 1), compared to the H-ZSM5 catalyst which demonstrated a lower selectivity of $73 \%$ isopulegol (Entry 4). This indicated that the H-NZ catalyst bears greater Lewis acidity than that of Brønsted acid behavior compared to the H-ZSM5 catalyst since lower amount of by products was formed.
Table 2. Effect of catalyst amount in the cyclisation of citronellal to isopulegol

\begin{tabular}{llcc}
\hline Entry & Catalyst & $\begin{array}{c}\text { Amount of } \\
\text { catalyst (wt\%) }\end{array}$ & $\begin{array}{c}\text { Selectivity } \\
(\%)^{\mathrm{a}}\end{array}$ \\
\hline 1 & H-NZ & 2.5 & 88 \\
2 & H-NZ & 5.0 & 86 \\
3 & H-NZ & 7.5 & 81 \\
4 & H-ZSM5 & 2.5 & 73 \\
5 & H-ZSM5 & 5.0 & 89 \\
6 & H-ZSM5 & 7.5 & 90 \\
\hline
\end{tabular}

Reaction conditions: citronellal $(25 \mathrm{~mL})$, reaction temperature $\left(100^{\circ} \mathrm{C}\right)$, reaction time $(3 \mathrm{~h})$, no solvent. ${ }^{\text {a Selectivity towards }}$ isopulegol, determined by GC analysis using an area ratio method.

Both Lewis acidity and Brønsted acidity are important during a cyclisation reaction, where previous studies revealed that the reaction mechanism of the cyclisation involves the coordination of citronellal to a strong Lewis acid followed by protonation from a Brønsted acid site (Chuah et. al., 2001). Further increasing the amount of catalyst to 5.0 and $7.5 \mathrm{wt} \%$ resulted in the decrease of isopulegol selectivity to 86 and $81 \%$, respectively (Entry 2 and $3)$.

This is due to the formation of by-products from side reactions. Meanwhile, the selectivity of H-ZSM5 catalyst improved with increased amount of catalyst, giving $89 \%$ selectivity at $2.5 \mathrm{wt} \%$ (Entry 5) and $90 \%$ selectivity at $7.5 \mathrm{wt} \%$ (Entry 6).

\section{Cyclisation of citronellal using bentonite based solid acid catalyst}

A catalyst with both Lewis and Brønsted acid behaviour is desired in the cyclisation of citronellal to isopulegol, however, a catalyst with greater Lewis acidity has been reported to be more favorable since it can decrease the formation of byproducts during the reaction (Vandichel et. al., 2013).

In order for further investigation the role of the acid type in the catalyst; natural bentonites (NB) was acid treated (H-NB) in a similar way and tested for the cyclisation reaction. Bentonites are suggested to readily exchange their interlayer cations with protons when treated with acid, generating higher amount of Brønsted acidity than that of Lewis acidity compared to zeolites.

Results of the cyclisation of isopulegol using bentonite and zeolite based solid acid catalysts are shown in Figure 1. Results of Bentonite based H-NB demonstrated relatively low isopulegol selectivity of only $31 \%$ in the cyclisation of citronellal whereas the parent NB showed lower results of $25 \%$.

The low selectivity was due to the formation of undesired by-products. Zeolite based solid acid catalyst on the other hand, gave $46 \%$ selectivity without treatment and the acid treated $\mathrm{H}-\mathrm{NZ}$ catalyst gave a significant increase in the selectivity up to $86 \%$. 


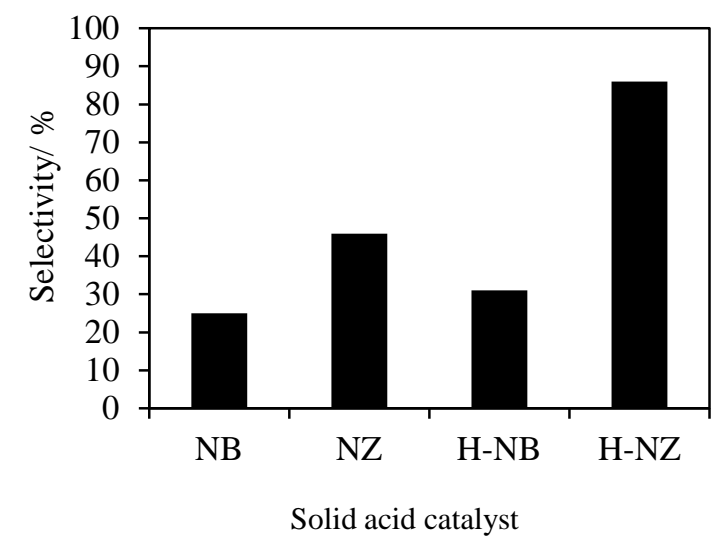

Figure 1. Cyclisation of citronellal to isopulegol using bentonite and zeolite based catalyst. Reaction conditions: citronellal $(25 \mathrm{~mL})$, reaction temperature $\left(100^{\circ} \mathrm{Cr}\right)$, eaction time $(3 \mathrm{~h})$, no solvent. Selectivity toward isopulegol, determined by GC analysis using an area ratio method.

Therefore it is highly assumed that the zeolite based catalyst has higher Lewis acidity than that of the bentonite, giving a rise in the overall selectivity of isopulegol.

\section{CONCLUSIONS}

Zeolite based solid acid catalyst was found to be active in the cyclisation of citronellal to isopulegol. An increase in the selectivity of isopulegol was observed when natural zeolite was treated with acid, giving the $\mathrm{H}-\mathrm{NZ}$ catalyst a superior catalytic activity compared to that of the commercially available $\mathrm{H}$ ZSM5 catalyst and bentonite based solid acid catalyst.

The best selectivity of $86 \%$ isopulegol was achieved using $2.5 \mathrm{wt} \% \mathrm{H}-\mathrm{NZ}$ catalyst at mild reaction conditions without the use of any solvent.

\section{REFERENCES}

Centi, G., \&Perathoner, S. (2008). Catalysis by layered materials: A review. Micropor. Mesopor. Mat. 107, 3-15.

Chuah, G. K., Liu, S. H., Jaenicke, S., \&Harrison, L. J. (2001). Cyclisation citronellal to isopulegol catalysed by hydrous zirconia and other solid acids. J. Catal., 200, 352-359.

Jacob, R. G., Perin, G., Loi, L. N., Pinno, C. S., \&Lenardao, E.J. (2003). Green synthesis of (-)isopulegol from (+)-citronellal: application to essential oil of citronella. Tetrahedron Letters, 44, 3605-3608.

Newman, C. P. (1998). Preparation of Isopulegol. International Patent Classification C07C 29/56, 35/08.

Vandichel, M., Vermoortele, F., Cottenie, S., De Vos, D. E., Waroquier, M., \& Van Speybroeck, V. (2013). Insight in the activity and diastereoselectivity of various Lewis acid. $J$. Catal., 305, 118-129. 